\title{
Review
}

\section{Intermittent catheterization: which is the optimal technique?}

\author{
JJ Wyndaele*,1 \\ ${ }^{1}$ Department of Urology, University of Antwerpen, Belgium
}

\begin{abstract}
Study design: Literature review to evaluate the practical techniques used for intermittent catheterization (IC) and intermittent self-catheterization (ISC).

Objectives: To ascertain the requirements for proper IC and ISC. To evaluate if a best technique exists.

Methods: Relevant articles on the subject are reviewed.

Conclusion: There is a wide variety of materials and techniques applied for IC and ISC. This does not seem to change the practical outcome much if the basic principles are used: good education and training, clean and atraumatic technique, good patient compliance in the longterm. There is neither one best technique nor one best material for IC. Both depend greatly on the patient's individual anatomic, social and economic state.
\end{abstract}

Spinal Cord (2002) 40, 432-437. doi:10.1038/sj.sc.3101312

Keywords: urinary bladder; catheterization; spinal cord; neurogenic bladder; urine

\section{Introduction}

Intermittent catheterization (IC) and self-catheterization (ISC) have become widely introduced during the last 40 years. ${ }^{1,2}$

The main aims of IC and ISC are to empty the bladder and to prevent bladder overdistension in order to avoid complications and to improve urological function. Many studies showed good results in continence with less complications leading to a better prognosis and a better quality of life in many patients with neurogenic bladder. ${ }^{3-5}$ A literature survey of results on continence is given in Table 1 .

IC and ISC are nowadays considered as the methods of choice for the management of neurological bladder dysfunction. ${ }^{6}$ In this paper we deal with data concerning IC and ISC techniques in order to find out if an optimal technique exists. Catheterization techniques involve types of catheters, lubricants, the catheter manipulation and introduction and the rules needed for a short-term and long-term successful application.

Many types of catheters are used, eg Nelaton, O'Neil, Tiemann and Foley. They are made of rubber, latex, plastic (PVC), silicone. They may be siliconized or of Teflon coated rubber, glass or stainless steel. Some are packed in a sheet/bag, ${ }^{7}$ others are reusable. A urethral introducer has been described which allows bypass of the colonized $1.5 \mathrm{~cm}$ of the distal urethra and which results in a significant lower infection rate

*Correspondence: JJ Wyndaele, Department of Urology, UZA, 10 Wilrijkstraat, B 2650 Edegem, Belgium in hospitalized men with spinal cord injury. ${ }^{8}$ Studies comparing materials in a randomized controlled way are scarce. Some recent studies evaluate mainly different hydrophilic catheters. In an animal study in the rabbit, Lundgren et $a l^{9}$ found that osmolality of hydrophilic catheters is important in regards to removal friction and urethral trauma. To minimize the risk of urethral trauma high osmolality catheters are recommended especially when the catheterization times are a few minutes or more. Waller et al ${ }^{10}$ compared two different hydrophilic catheters in a cross-over study of 14 male spinal cord injury patients, as to the maximum friction force during the removal of the catheters after bladder emptying. The catheter with the highest osmolality (approximately $900 \mathrm{mOsm} /$ $\mathrm{kg}$ ) had much less sticking to the urethral epithelium and had a significantly lower friction force. BieringSorensen et $a l^{11}$ compared two types of hydrophilic catheters and found no difference regarding the number of urethral epithelial cells on the surface of the catheters after catheterization. Wyndaele et al ${ }^{12}$ evaluated the use of a hydrophilic catheter in 39 male patients with neurogenic bladder using conventional catheters over a long period of time. The hydrophilic catheter proved as easy to use but was better tolerated. Satisfaction was better especially in patients who experienced problems with conventional catheters. Some patients were unsatisfied for reasons of practical use or for economical reasons. Very recently Hedlung et $a l^{13}$ asked for a prospective, randomized long-term multicenter study in order to reach reliable conclusions 
Table 1 Outcome of continence

\begin{tabular}{|c|c|c|c|c|}
\hline Authors & $\begin{array}{l}\text { Number of } \\
\text { patients }\end{array}$ & Follow-up & $\begin{array}{l}\text { Adjunctive } \\
\text { treatment }\end{array}$ & $\begin{array}{l}\text { Result of } \\
\text { continence }\end{array}$ \\
\hline Madersbacher and Weissteiner ${ }^{48}$ & 12 women & $2-4$ years & & $\begin{array}{l}50 \% \text { dry, other } 50 \% \\
\text { some grade of } \\
\text { incontinence }\end{array}$ \\
\hline Wyndaele et $a l^{49}$ & $30(18 \mathrm{~m}, 12 \mathrm{f})$ & 3-30 months & $\begin{array}{l}6 \text { anticholinergic, } \\
1 \text { colocystoplasty }\end{array}$ & $\begin{array}{l}73 \% \text { continent }+ \\
13 \% \text { improvement }\end{array}$ \\
\hline Iwatsubo et $a l^{50}$ & $\begin{array}{l}60 \text { spinal cord } \\
\text { lesion }\end{array}$ & & $\begin{array}{l}\text { Overdistension } \\
\text { during shockphase }\end{array}$ & $100 \%$ continent \\
\hline McGuire and Savastano 51 & $22 \mathrm{f}$ & 2-11 years & Surgery $27 \%$ & Continent $73 \%$ \\
\hline Kornhuber and Schultz ${ }^{52}$ & $\begin{array}{l}197 \text { multiple } \\
\text { sclerosis }\end{array}$ & & & $\begin{array}{l}\text { Continence } \\
\text { improved with } \\
\text { elimination of } \\
\text { residual urine }\end{array}$ \\
\hline Wyndaele and Maes ${ }^{53}$ & 75 (69 neurogenic) & $1.5-12$ years & 38 anticholinergics & $\begin{array}{l}47 \text { dry, } 22 \text { seldom } \\
\text { wet, } 6 \text { wet at least } \\
\text { once a day }\end{array}$ \\
\hline Kuhn et $a l^{54}$ & $\begin{array}{l}22 \text { spinal cord } \\
\text { lesion }\end{array}$ & 5 years & No & $\begin{array}{l}\text { Continence did not } \\
\text { change }\end{array}$ \\
\hline Lindehall et $a l^{55}$ & 26 meningomyelocoele & $7.5-12$ years & & 24 out of 26 better \\
\hline Waller et $a l^{56}$ & $\begin{array}{l}30 \text { spinal cord } \\
\text { lesion }\end{array}$ & 5-9 years & 6 anticholinergics & $\begin{array}{l}22 \text { dry, } 8 \\
\text { incontinent }\end{array}$ \\
\hline Vaidyanathan et $a l^{57}$ & $\begin{array}{l}7 \text { spinal cord } \\
\text { lesion }\end{array}$ & 14-30 months & $\begin{array}{l}\text { Bladder relaxant } \\
\text { drugs intravesically }\end{array}$ & $\begin{array}{l}84 \% \text { dry, } 3 \\
\text { dampness at } \\
\text { awaking }\end{array}$ \\
\hline
\end{tabular}

$\mathrm{f}=$ female $; \mathrm{m}=$ male

concerning hydrophilic catheters. Studies comparing the use hydrophilic catheters with the use of ordinary catheters and lubricant must take into account how this lubricant jelly is used: applied on the catheter or injected into the urethra. So far one can only wait until such studies are performed before claiming the superiority of either.

Most catheters need the use of some kind of lubricants, especially in men, eg jellies or aqueous solution. Lubricants are applied on the catheter or are instilled into the urethra. ${ }^{14}$ In some countries patients use oil ${ }^{15}$ or just water ${ }^{16}$ as lubricant. For those with preserved urethral sensation, a local anaesthetic jelly may be needed. These jellies would seem most effective when instilled into the urethra before catheterization. Many female patients do not use catheter lubrication. Catheters with a hydrophilic and self lubricated surface need activation with tap or sterile water.

Regarding the size of the catheters, for adults $10-$ $14 \mathrm{Fr}$ for males and 14-16 Fr for females are mostly used but bigger size/lumen may be necessary for those with bladder augmentation or cloudy urine from other origin. No studies on IC compared sizes in a randomized way. Two main techniques have been adopted, a sterile (SIC) and a clean IC (CIC). The sterile non-touch technique advocated by Guttmann and Frankel involves the use of sterile materials handled with sterile gloves and forceps. In an intensive care unit, some advocate wearing a mask and a sterile gown as well. In some centers, during a bladder training program SIC used to be done only by a catheter team, which has proven to obtain a very low infection rate. ${ }^{17}$ Nowadays the sterile technique is mostly used only during a restricted period of time and in a hospital setting. In the majority of cases a clean technique is used.

Self-catheterization is carried out in many different positions: supine, sitting or standing. Female patients may use a mirror or a specially designed catheter to visualize the meatus. ${ }^{18}$ After a while most women do not need these aids anymore.

The basic principles of urinary catheter introduction are well known: the catheter must be introduced in a non-infecting and atraumatic way. The requirements for this have been described before. Non-infecting means cleaning hands, using a non-infected catheter and lubricant and cleaning the meatal region before catheter introduction. Here again different ways of application exist: the use of sterile components with the catheter introduced out of the sheet into the urethra as well as the use of re-sterilized catheters introduced by hand which have been washed before. Individual variation can be found in every patient group.

Atraumatic requires a proper catheter size, sufficient lubrication, and gentle introduction through the urethra, sphincter area and bladder neck. ${ }^{19,20}$ The catheter has to be introduced until urine flows out. Urine can be drained directly in the toilet, in a urinal, plastic bag or other reservoir. The catheter should be kept in place until urine flow stops. Then it should be pulled out slowly while gentle Valsalva or bladder expression is carried out in order to completely drain residual urine. When properly done the residual urine 
should be a maximum $6 \mathrm{ml}$ as demonstrated by Stribran and Fabian with phenolphthalein washing. ${ }^{21}$ But that the daily truth can be different was shown by Jensen et $a .^{22}$ These authors measured residual urine repeatedly with ultrasonography and found rest urine in $70 \%$ of the catheterizations in their group of 12 patients with spinal cord lesion. The residual could exceed $50 \mathrm{ml}$ and even $100 \mathrm{ml}$.

Finally, the end of the catheter should be blocked to prevent backflow of the urine or air into the bladder. Hydrophilic catheters can be left in place for a short time only to prevent suction by the urethral mucosa which may make removal difficult.

During the rehabilitation phase clean ISC (CISC) can be taught early to patients with good hand function. Wyndaele and De Taeye ${ }^{23}$ compared the results in 25 paraplegic patients (23 men and two women) started on CISC at a mean of 35 days ( 7 to 85 days) post trauma with those in 48 paraplegic patients catheterized by nurses with a non-touch technique and found comparable results in final outcome of the bladder training, and infection rate. Early selfcatheterization allowed the patient to go home for weekends earlier and was considered positive by the majority of those participating. Champion ${ }^{24}$ found no bacteriological difference in urine specimens 1 year after 7 patients were changed from sterile to clean ISC.

When resources are limited, catheters are re-used for up to weeks and months. Some re-sterilize or clean them by soaking in an antiseptic solution or boiling water. Microwave to re-sterilize rubber catheters has been described by Silbar et $a l^{25}$ A silicone Japanese type self-catheter has proved to be reusable for a long time. $^{26,27}$ Van Hala et $a l^{28}$ used a questionnaire in 97 patients with pediatric onset neurogenic bladders to evaluate differences between IC with a sterile new catheter and IC with re-used material. Ninety-eight per cent used a clean technique. These data suggest that re-used supplies are not related to an increased likelihood of urinary tract infection.

The frequency of catheterization needed can depend on many factors such as bladder volume, fluid intake, post-void residual and urodynamic parameters (bladder compliance, detrusor pressure). Usually it is recommended to catheterize $4-6$ times a day during the acute phase after spinal cord lesion. Some will need to keep this frequency if IC is the only way of bladder emptying. Others will catheterize $1-3$ times a day to check and evacuate residual urine after voiding or on a weekly basis during bladder retraining. ${ }^{29}$ Clinical utility of a portable ultrasound device in IC has been evaluated in randomized controlled trials. ${ }^{30,31}$ The results show that the device allows a reduction in the number of required catheterizations and is associated with a high degree of patient satisfaction.

Adjunctive therapy to overcome high detrusor pressure is often needed. Anticholinergic drugs or bladder relaxants are often indicated in patients with bladder overactivity. For those who develop a low compliance bladder, upper tract deterioration or severe incontinence injection of botulinum toxin in the bladder wall $^{32}$ or surgery as bladder augmentation ${ }^{33}$ may be necessary. Where a too high diuresis is noted during the night due to diurnal variation of antidiuretic hormone, ${ }^{34}$ DDAVP can safely and effectively be used. $^{35}$ In cases of catheterization difficulty at the striated sphincter, botulinum toxin injection in the sphincter can help. ${ }^{36}$ In individuals with tetraplegia reconstructive handsurgery may be indicated. ${ }^{37}$ For those with poor handfunction or difficulty in reaching the meatus, assistive devices might be needed. ${ }^{38}$

Education is very important. Patients and carers must understand what is wrong with the bladder/ sphincter and why IC is proposed for treatment. They have to learn how to catheterize properly. Teaching programmes have been successful in non-literate persons in developing countries ${ }^{39}$ and in quadriplegic patients. ${ }^{40}$

It is clear that IC can improve incontinence or can make patients with neurogenic bladder continent if bladder capacity is sufficient, bladder pressure kept low, urethral resistance high enough, and if care is taken to balance between fluid intake, residual urine and frequency of catheterization.

Not all patients starting with IC continue this treatment. Some reasons for this are given in studies summarized in Table 2. Perrouin-Verbe et $a l^{41}$ found in their global population of 159 spinal cord injury patients that only eight having practised CIC for at least 2 years stopped the technique, indicating that in spinal cord injury in most cases the definitive choice of voiding method is made within 2 years post injury. A

Table 2 Reasons for stopping intermittent self-catheterization

\begin{tabular}{|c|c|c|c|c|c|c|}
\hline Authors & $\begin{array}{l}\text { Catheter free } \\
(\%)\end{array}$ & $\begin{array}{l}\text { Incontinence } \\
(\%)\end{array}$ & $\begin{array}{l}\text { Inconvenient } \\
(\%)\end{array}$ & $\begin{array}{l}\text { Infection } \\
(\%)\end{array}$ & $\begin{array}{l}\text { Physical } \\
\text { status }(\%)\end{array}$ & $\begin{array}{l}\text { Choice of } \\
\text { patient }(\%)\end{array}$ \\
\hline Diokno et $a l^{58}$ & 17 & 2 & 2 & & 7 & \\
\hline Maynard and Glass ${ }^{59}$ & 12 & & & & & 6 \\
\hline Whitelaw et at ${ }^{60}$ & 5 & & 5 & & 5 & 5 \\
\hline Webb et $a l^{61}$ & 9 & & 3 & & 2 & 2 \\
\hline Timoney and Shaw ${ }^{62}$ & & 36 & & & & \\
\hline Sutton et $a l^{40}$ & & 6 & 6 & 3 & 3 & 3 \\
\hline Bakke ${ }^{63}$ & 10 & & 5 & 4 & 3 & \\
\hline Hunt et $a l^{64}$ & 10 & & & & & \\
\hline
\end{tabular}


main reason to stop was continuing incontinence. The first factor of acceptance of the technique was continence. The second factor of acceptance relates to the autonomy of the patients for practising IC. In their population of 50 patients Perkash and Giroux ${ }^{42}$ have also found that four out of seven tetraplegics had stopped IC because they needed to be catheterized by others. In their study a total of $66 \%$ had stopped IC mainly after surgery on sphincter and prostate or after initiation of voiding. Bakke and Malt $^{43}$ found that among those who practiced IC independently $25.8 \%$ were sometimes and $6 \%$ always averse. Young patients and females were more averse to CIC. In 30\% aversion seemed to be related to a subjective evaluation of their situation, to an emotional status and above all to nonacceptance of their chronic disability. In a recent study $^{44}$ a retrospective analysis was made on the compliance with bladder management in spinal cord injury patients. Of 38 patients on CIC at discharge $52 \%$ discontinued the method and reverted to indwelling catheter during follow-up. Dependence on care givers, spasticity interfering with catheterization, incontinence despite anticholinergic agents and lack of availability of external collective devices for female patients were the main reasons for stopping CIC.

Is IC cost-effective? There are no data about the cost and cost/efficacy as yet available. Prieto-Fingerhut et $a l^{45}$ compared the cost of sterile and non sterile IC and found that clean IC was less costly taking into account the price of sterile sets used for IC. Grundy et $a l^{46}$ compared the price of IC and suprapubic fine-bore catheterization after spinal cord injury and found the latter cheaper for material, average antibiotic cost and labour. Duffy et $a l^{47}$ evaluated cost-effectiveness in a population of male residents of VA nursing homes comparing CIC and SIC. In this randomized clinical trial they found a similar outcome but less expense if a clean technique was used.

In developing countries even a very low catheterization budget may be out of reach for the majority of patients. Re-use of inexpensive catheters and the use of a local product as lubricant may bring the method within the reach of more patients.

To conclude: there is a wide variety of materials used and techniques applied for IC. This does not seem to change the practical outcome much if the basic principles are applied: good education and training, clean and atraumatic technique, good patient compliance in the longterm. It is clear that there exists neither one best technique nor one best material for IC. Both depend greatly on the patient's individual anatomic, social and economic possibilities.

\section{References}

1 Guttmann L, Frankel $\mathrm{H}$. The value of intermittent catheterization in the early management of traumatic paraplegia and tetraplegia. Paraplegia 1966; 4: 63-83.
2 Lapides J, Diokno A, Silber S, Lowe B. Clean intermittent self catheterization in the treatment or urinary tract disease. J Urol 1972; 107: 458-461.

3 Maynard FM, Diokno A. Clean intermittent catheterization for spinal cord injured patients. J Urol 1982; 128: $477-480$.

4 Diokno AC, Sonda LP, Hollander JB, Lapides J. Fate of patients started on clean intermittent self-catheterization 10 years ago. J Urol 1983; 129: $1120-1122$.

5 Sutton G, Shah S, Hill V. Clean intermittent selfcatheterization for quadriplegic patients-a five year follow up. Paraplegia 1991; 29: $542-549$.

6 Madersbacher $\mathrm{H}$ et al. Conservative management in the neuropathic patient. In: Abrams P, Khoury S, Wein A (eds). Incontinence. Health Publications Ltd 1999, pp $775-812$.

7 Wu Y, Hamilton BB, Boyink MA, Nanninga JB. Reusable catheter for longterm intermittent catheterization. Arch Physic Med Rehab 1981; 62: 39-42.

8 Bennett CJ et al. The effect of urethral introducer tip catheters on the incidence of urinary tract infection outcomes in spinal cord injured patients. J Urol 1997; 158: $519-521$

9 Lundgren $\mathbf{J}$ et al. The importance of osmolality for intermittent catheterization of the urethra. Spinal Cord 2000; 38: $45-50$

10 Waller L, Telander M, Sullivan L. The importance of osmolality in hydrophilic urethral catheters a crossover study. Spinal Cord 1998; 36: 368 - 369.

11 Biering-Sorensen F, Nielsen K, Hansen HV. Urethral epithelial cells on the surface on hydrophilic catheters after intermittent catheterization: cross-over study with two catheters. Spinal Cord 1999; 37: 299-300.

12 Wyndaele $\mathrm{JJ}$ et al. Evaluation of the use of Urocath-Gel catheters for intermittent self-catheterization by male patients using conventional catheters for a long time. Spinal Cord 2000; 38: $97-99$.

13 Hedlund $\mathrm{H}$ et al. Hydrophilic versus non-coated catheters for intermittent catheterization. Scand J Urol Nephrol 2001; 35: 49-53.

14 Burgdörfer $\mathrm{H}$ et al. Manual-Neuro-urology and Spinal Cord lesion. Edited by the working party on Urological rehabilitation of Spinal Cord Injury Patients of the German Speaking area.

15 Kovindha, 1998, personal communication

16 Orikasa $\mathrm{S}$ et al. Experience with non-sterile intermittent self-catheterization. J Urol 1976; 115: $141-142$.

17 Lindan R, Bellomy V. The use of intermittent catheterization in a bladder training program, preliminary report. J Chron Dis 1971; 24: 727-735.

18 Bruijnen CLAH, Boer PW. Intermittent self-catheterization: a new instrument. Br J Urol 1981; 53: 198.

19 Wyndaele JJ. Early urological treatment of patients with an acute spinal cord injury. Thesis Doctor in Biomedical Science. State University Ghent 1983.

20 Corcos J. Traitements non médicamenteux des vessies neurogènes. In: Corcos J, Schick E (Eds) Les vessies neurogènes de l'adulte. Masson Paris, 1996, pp 173-187.

21 Stribrna J, Fabian F. The problem of residual urine after catheterization. Acta Univ Carol Med 1961; 7: 931-935.

22 Jensen AE, Hjeltnes N, Berstad J, Stanghelle JK. Residual urine following intermittent catheterisation in patients with spinal cord injuries. Paraplegia 1995; 33: $693-696$ 
23 Wyndaele JJ, De Taeye N. Early intermittent self catheterization after spinal cord injury. Paraplegia 1990; 28: $76-80$.

24 Champion VL. Clean technique for intermittent selfcatheterization. Nurs Res 1976; 25: $13-18$.

25 Silbar E, Cicmanec J, Burke B, Bracken RB. Microwave sterilization. Method for home sterilization of urinary catheter. J Urol 1980; 141: 88 -90.

26 Igawa, 1998, personal communication.

27 Kovindha A, Na W, Madersbacher H. Radiological abnormalities in spinal cord injured men using clean intermittent catheterization with a re-usable silicone catheter in developing country. Poster 86 presented during the Annual Scientific meeting of IMSOP Sydney 2000. Abstract book p 112.

28 Van Hala S et al. Bladder management in patients with pediatric onset neurogenic bladders. J Spinal Cord Med 1997; 20: $410-415$.

29 Opitz JL. Bladder retraining: an organized program. Mayo Clin Proc 1976; 51: 367-372.

30 Anton HA, Chambers K, Clifton J, Tasaka J. Clinical utility of a portable ultrasound device in intermittent catheterization. Arch Phys Med Rehab 1998; 79: $172-$ 175.

31 De Ridder D, Van Poppel H, Baert L, Binard J. From time dependent intermittent self catheterization to volume dependent self catheterization in multiple sclerosis using the PCI 5000 Bladder manager. Spinal Cord 1997; 35: 613-616.

32 Schurch B et al. Botulinum-A toxin for treating detrusor hyperreflexia in spinal cord injured patients: a new alternative to anticholinergic drugs? Preliminary results J Urol 2000; 164: 692-697.

33 Mast $\mathrm{P}$ et al. Experience with augmentation cystoplasty. A review. Paraplegia 1995; 33: 560-564.

34 Kilinc S, Akman MN, Levendoglu F, Ozker R. Diurnal variation of antidiuretic hormone and urinary output in spinal cord injured. Spinal Cord 1999; 37: $332-335$.

35 Chancellor MB, Rivas DA, Staas Jr WE. DDAVP in the urological management of the difficult neurogenic bladder in spinal cord injury: preliminary report. $J \mathrm{Am}$ Paraplegia Soc 1994; 17: 165 - 167.

36 Wheeler Jr JS, Walter JS, Chintam RS, Rao S. Botulinum toxin injections for voiding dysfunction following sci. $J$ Spinal Cord Med 1998; 21: 227-229.

37 Kiyono Y, Hashizume C, Ohtsuka K, Igawa Y. Improvement of urological-management abilities in individuals with tetraplegia by reconstructive hand surgery. Spinal Cord 2000; 38: 541-545.

38 Bakke A, Vollset SE. Risk factors for bacteriuria and clinical urinary tract infection in patients treated with clean intermittent catheterization. J Urol 1993; 149: 527 531.

39 Parmar S, Baltej S, Vaidynanathn S. Teaching the procedure of clean intermittent catheterization. Paraplegia 1993; 31: $298-302$

40 Sutton G, Shah S, Hill V. Clean intermittent selfcatheterization for quadriplegic patients - a five year follow up. Paraplegia 1991; 29: 542 - 549.

41 Perrouin-Verbe B et al. Clean intermittent catheterization from the acute period in spinal cord injury patients. Longterm evaluation of urethral and genital tolerance. Paraplegia 1995; 33: 619-624.

42 Perkash I, Giroux J. Clean intermittent catheterization in spinal cord injury patients: a follow up study. J Urol 1993; 149: 1068 - 1071
43 Bakke A, Malt UF. Psychological predictors of symptoms of urinary tract infection and bacteriuria in patients treated with clean intermittent catheterization: a prospective 7 year study. Eur Urol 1998; 34: 30-36.

44 Yavuzer $\mathrm{G}$ et al. Compliance with bladder management in spinal cord injury patients. Spinal Cord 2000; 38: 762 765.

45 Prieto-Fingerhut T, Banovac K, Lynne CM. A study comparing sterile and nonsterile urethral catheterization in patients with spinal cord injury. Rehabil Nurs 1997; 22: $299-302$

46 Grundy DJ et al. A comparison of fine-bore suprapubic and an intermittent urethral catheterization regime after spinal cord injury. Paraplegia 1983; 21: $227-232$.

47 Duffy LM et al. Clean intermittent catheterization: safe, cost-effective bladder management for male residents of VA nursing homes. $J$ Am Geriatr Soc 1995; 43: 865-870.

48 Madersbacher $\mathrm{H}$, Weissteiner $\mathrm{G}$. Intermittent selfcatheterization, an alternative in the treatment of neurogenic urinary incontinence in women. Eur Urol 1977; 3: 82 - 84 .

49 Wyndaele JJ, Oosterlinck W, De Sy W. Clean intermittent self-catheterization in the chronical management of the neurogenic bladder. Eur Urol 1980; 6: 107-110.

50 Iwatsubo E et al. Over-distension therapy of the bladder in paraplegic patients using self-catheterisation: a preliminary study. Paraplegia 1984; 22: $201-215$.

51 McGuire EJ, Savastano J. Comparative urological outcome in women with spinal cord injury. J Urol 1986; 135: $730-731$

52 Kornhuber HH, Schutz A. Efficient treatment of neurogenic bladder disorders in multiple sclerosis with initial intermittent catheterization and ultrasound-controlled training. Eur Neurol 1990; 30: 260-267.

53 Wyndale JJ, Maes D. Clean intermittent self-catheterization: a 12 year follow up. J Urol 1990; 143: 906-908.

54 Kuhn W, Rist M, Zach GA. Intermittent urethral selfcatheterisation: long term results (bacteriological evolution, continence, acceptance, complications). Paraplegia 1991; 29: $222-232$.

55 Lindehall B, Moller A, Hjalmas K, Jodal U. Long-term intermittent catheterization: the experience of teenagers and young adults with myelomeningocoele. J Urol 1994; 152: $187-189$

56 Waller L, Jonsson O, Norlén L, Sullivan L. Clean intermittent catheterization in spinal cord injury patients: long-term follow up of a hydrophilic low friction techniques. J Urol 1995; 153: 345-348.

57 Vaidyanathan $\mathrm{S}$ et al. Effect of intermittent urethral catheterization and oxybutinen bladder instillation on urinary continence status and quality of life in a selected group of spinal cord injury patients with neuropathic bladder dysfunction. Spinal Cord 1998; 36: 409-414.

58 Diokno AC, Sonda LP, Hollander JB, Lapides J. Fat of patients started on clean intermittent self-catheterization 10 years ago. J Urol 1983; 129: $1120-1122$.

59 Maynard FM, Glass J. Management of the neuropathic bladder by clean intermittent catheterization: 5 year outcomes. Paraplegia 1987; 25: $106-110$.

60 Whitelaw S, Hamonds J, Tregallas R. Clean intermittent self-catheterization in the elderly. $B r J$ Urol 1987; 60: $125-127$

61 Webb R, Lawson A, Neal D. Clean intermittent selfcatheterization in 172 adults. Br J Urol 1990; 65: 20-23. 
62 Timoney AG, Shaw PJ. Urological outcome in female patients with spinal cord injury: the effectiveness of intermittent catheterization. Paraplegia 1990; 28: $556-$ 563.

63 Bakke A. Clean intermittent catheterization-physical and psychological complications. Scan J Urol Nephrol Suppl 1993; 150: $1-69$.
64 Hunt GM, Oakeshott P, Whitacker RH. Intermittent catheterization: simple, safe and effective but underused. BMJ 1996; 312: $103-107$. 